\title{
The Big Bang of Neoliberal Urbanism: The Gigantomachy of Santiago's Urban Development
}

\begin{abstract}
This study presents a spatial history of the origins of Santiago's neoliberalisation, unveiling its urban history from the critical point of view of land at the centre of social classes' dispute over city life. It situates the contestation and struggle over land in a genealogical progression from the origins of the disciplinary field of urbanism (1932) to the transformation of its regulatory framework, making it an exclusively profitoriented practice complementary to processes of wealth creation through urban transformations (1979). As an allegory, we used the Gigantomachy to interpret these struggles. Special emphasis is given to the land struggles that occurred in Santiago as a part of this migratory process and how the contestation of private land became an alternative to the government's incapacities to resolve the urban poor condition. This contestation would lead to the dominant class looking for alternative politics that ensure the defence of their property. This study presents neoliberalism as a response to such a call. Neoliberalism in Santiago was the way to transform the problem of housing scarcity in big business for the dominant class. The study historically outlines this process in what may be considered as the first neoliberal urban policy in the world, depicting the big bang of neoliberal urbanism.
\end{abstract}

Keywords: neoliberalism; urban policy; planning; political economy; urbanism 


\section{Introduction}

The main objective of this paper is to offer an interpretation of the spatio-political causes that fuelled the coup d'état in Chile and the subsequent emergence of a fierce defense of private property and, therefore, a complete neo-liberalization. A range of literature (Salcedo and Rasse, 2012; Scarpaci et al., 1988) has presented how the intention of reducing residential segregation during Frei's and Allende's governments increased the tension between social classes, but limited attention has been paid to the way how such spatial changes have permanently altered the ideological foundations of neoliberalism.

Aiming to contribute to fill this gap, this paper offers a historical narrative of how the coup d'état and its spatial causes have generated what Henri Lefebvre called a critical point of an implosion-explosion process (Lefebvre, 2003) infused by extra-capitalist practices of violence to provide the spark that leads to the explosion of capitalism, the big-bang of urban neoliberalism. Excavating the urban history of Santiago, we were able to trace such a bigbang moment to the contestation of land rights in Las Condes, after Allende's first social housing estate near a high-class neighborhood of Santiago.

In order to grasp the spatial complexity and the violent nature of neoliberalisation of space in Santiago, the paper complements its intellectual scaffolding with Mezzadra and Gago's (2017) acknowledgment of extractivism as a violent form of territorial capitalism. Methodologically speaking, the paper is intended to complement the excavation of the recent urban history of Santiago, adopting the method of social history based on Hobsbawm (1971) and the Chilean historians Gabriel Salazar and Julio Pinto (2014). The principles of new social history informed the new urban history in which social issues have a significant influence over urban processes (Celik and Favro, 1988). The paper, thus, articulates the historical narrative of the politics of the city and its spatial transformations to provide a novel interpretation of the possible causes that triggered the neoliberal process.

Santiago is considered the first city in the world where neoliberalism was implemented in 1975 (Brenner et al., 2012; Harvey, 2005; Klein, 2011) and therefore it constitutes an archaeological-like example for studying neoliberal urban practices and the spatial consequences of its implementation. Unpacking urban Santiago's spatial history, the paper 
develops an analysis on its neoliberal transformation as a response to the contestation around private property in Santiago's high-class clusters. After briefly outlining the key spatial dimensions of neoliberalism that help to situate and frame the subsequent historical evolution, the paper describes the democratization of the city during the governments of Eduardo Frei Montalva (1964-1969) and Salvador Allende (1970-1973), and the main political transformations related to urban policy implemented during the dictatorship of Pinochet.

\section{Neoliberalism and extractivims: basic coordinates}

Neoliberalism is a 'slippery concept' examined from a multiplicity of conceptual categories and disciplinary realms: from cities to labour, from sexuality to race (Springer, 2016). It has "no fixed or settled coordinates [...] policy entailments, and material practices (Brown, 2016: 20). Most scholars tend to agree that neoliberalism is broadly defined as the extension of competitive markets into all areas of life, including the economy, politics, and society" (Springer, 2016: 2). Despite the amorphous and polysepalous dimensions, neoliberalism is a material reality where all of us are immersed (Boano, 2017). Wendy Brown defines neoliberalism "as an economic policy, a modality of governance, and an order of reason is at once a global phenomenon, yet inconstant, differentiated, unsystematic, impure" (2016: 20) but its practice emerged from an influential group of liberal thinkers who organised to contest Keynesian economic theory ${ }^{[1]}$ in a post-war context in Europe and USA. The motivation was to produce an alternative governance towards the realisation of economic freedom "as the extension of competitive markets into all areas of life, including the economy, politics and society" (Springer, 2016: 2). Neoliberalism is also a governmental model that eliminates control over prices and advances toward the privatisation of social security (Boas and GansMorse, 2009). In this paper, we adopted David Harvey's definition of neoliberalism which is "either as a utopian project to realise a theoretical design for the reorganisation of international capitalism or as a political project to re-establish the conditions for capital accumulation and to restore the power of economic elites" (2005: 19). Neoliberalism has a spatial face represented in its modes of urban development. 
While the urbanisation of neoliberalism refers to a broader scale of analysis, its representation at microscale is significant for getting into how this ideology has transformed the way we see cities. For instance, neoliberalism fosters individualism (Stiglitz, 2010), and one of the main spatial expressions of individualised space is the dwelling. We acknowledge that urban neoliberalism refers to how such ideological project is producing the form, the image and the life in the cities. As Keil suggests, urbanisation neoliberalism has a material and discursive practice through which modern capitalist societies are being reproduced (Keil in Springer, 2016). Neoliberal urbanism is then a descriptive category that can depict the spatiotemporal material and its operative analytical capacity of producing urban space. Under neoliberalism, the push for homeownership by governments has been a common feature (Rossi and Vanolo, 2015), so understanding its spatial features from housing policies is one of the common strategies followed by its critics. Also, for global financial institutions, the housing provision under neoliberalism has been strategic for increasing wealth. Starting in the early 1990s, after the Washington Consensus, banks have reduced the requirements for credits on mortgages which facilitated the access to homeownership at the time that involved the financial sector more actively in the production of spaces (Fernandez and Aalbers, 2016). A new aesthetics of cities during neoliberalism depends, in a good share, of the objectives of financial institutions, favouring certain typological spaces that ensure the profitability of investments (Cattaneo Pineda, 2011). The access of low-income communities to multiple mortgages without financial background and the coercion of the financial sector to maximise the earnings from the housing market were the main causes of the financial crisis of 2008 (Follain and Giertz, 2012). A critical reflection of how neoliberalism occupied the disciplinary fields related to urban development is a much-needed approach to unpacking how such ideological project affected cities and its inhabitants.

Neoliberalism expanded the idea of an entrepreneurial society, and it produced several effects in cities. David Harvey illustrated the idea of entrepreneurial cities as spaces where politicoeconomic elites work together for experimenting through innovative ways of capital accumulation which implied a series of socio-spatial restructuring processes as consequence of the speculative dynamics that had driven these entrepreneurial strategies (Rossi and 
Vanolo, 2015). Neoliberalism and spatiology is also a truth game as "its accounts of human knowledge, social complexity and the economic market legitimate its management of individuals $[\ldots]$ that the economic market is better able to calculate, process and spontaneously order society than the state is able to [...] The function of architecture prescribed by this position is that of producing endlessly flexible environments for infinitely adaptable subjects." (Spencer, 2016: 3-4). The breakpoint between a pre-neoliberal way of making cities and its neoliberalisation is not so clear in literature and requires further development. The Chilean case is illustrative in this matter.

In Chile, pre-neoliberal modes of city planning were marked by the state planning the urban space based on the conviction that its role was ensuring dignity for people by providing basic services such as education, health and housing (Hidalgo-Dattwyler, 2019). Prior to neoliberalization, the Chilean governments of Frei and Allende advanced toward a welfare state in which the development model intensified the investment of public funds in the internal economy (Salazar and Pinto, 2014). In relation to housing, the Chilean government institutionalised the supply of housing solutions. Technical functions allowed the state to define the national priorities in relation to urban development, planning land use and housing allocation and articulating public bids to engage with the private to construct the projects. In this relationship, the private rents were agreed with the public institutions to ensure the correct assignment of the national budget in urban initiatives. Also, the free market operated in other areas of the city based on private real estate development as well, and the state focused only to organize the supply for low-income and middle-class households (Miguel Lawner in Boano and Vergara-Perucich, 2017). After neoliberalization, the free-market economy undertook the whole urban development process, and the leading role of the state was dismantled (Valencia, 2007).

From the return to democracy in 1990, Santiago's urban development has been under a market-oriented predominance in deciding the future of cities, changing lifestyles of inhabitants, increasing needs of mobility and organising the residential areas by household's purchasing power. Because of the speed of such changes, the city of Santiago has become more fragmented and uneven (Bresciani L. in Greene et al., 2011). The origins of the 
segregated city can be found in the dictatorship period when the urban planning institutions changed drastically. An urban development model under a neoliberal regime was implemented for the first time in Chile, and particularly in Santiago, by a new urban policy introduced in 1979 (Daher, 1990). This policy defined that the urban space should be planned by market rules (supply and demand, cost-benefit, and profitability of interventions). The Chilean dictatorship of Augusto Pinochet converted urban development into a set of profitoriented practices, with a particular focus on housing. Although critical reflections on the neoliberalisation of urban practices are abundant the image and the objectives that motivated its implementation in the urban realm are still open to discussion, and it started in Santiago de Chile.

\section{The Gigantomachy: Urbanism at the center of the battle of extractions}

As in gigantomachy, the mythological battle between giants and citizens, the monstrosity of contemporary capitalism in its multiple and ever-evolving forms demands careful analysis. In particular, the spatio-temporal stratifications of the mechanisms that have allowed current economic powers to capture life itself must be scrutinized. Mezzadra and Gago's (2017) acknowledgment of extractivism as a violent form of territorial capitalism and its intricate relationship with financialization into an intertwined, mutually reinforcing set of tendencies and transformations within the realms of economics, politics, society and culture (Rolnik, 2013) are an important reflection to add. The neo-liberalization of Santiago was similar to this battle in which a government for the people, advancing toward a more inclusive society with new spaces for everyone, was smashed by an authoritarian government aiming to clearly define the urban space by clusters of social classes. That, in turn, inverted the inclusion attempted by Frei and Allende's governments.

The Gigantomachy alluded to in the title here was probably the most important battle that happened in Greek mythology. The conflict pitted against each other the Giants sons of Gaea and Uranus, and the Olympian gods who were trying to overthrow the old religion and establish themselves as the new rulers of the cosmos. The gods finally prevailed through the aid of Heracles the archer, and the Giants were slain. The point in going back to this 
illustrative mythology is to suggest that the full depth of violence reaches its apex during war, after which there is a power vacuum awaiting colonization. In short, war (in its many manifestations) facilitates the arrival of endings, of transformational finishing points. By introducing increased velocities of violent engagement, war leaps with the thirst of conclusion: defeating an adversary, conquering territory, annihilating and promoting the notion of a tabula rasa, extracting resources and values, bringing with it the phantasmagoria of new power assemblages, engendered by the violent gestures of physical confrontation and topologies which may, in cases, "expose the rickety scaffoldings of the state and gesture to its often violent refounding" (Rosas, 2007: 97), or develop in the fringes of sovereignty, at the intersection of capitalism and violence.

Urbanism lies at the centre of such restless battles, due to its plastic capacity to encompass changes, mutations and transformations, adapting itself to the double force of explorationand-invention, dispossession-and-creation. Whether we all know that spatial solutions are largely inherent in capitalism (Harvey, 2005), the characteristic of capital as a dominant social relation is a product of the dynamics of valorization, the contradictions of which tend to lead to recurrent crises of overaccumulation. Following the suggestion of Gago and Mezzadra, there is the need to frame the paradigms of privatization and financialization with one of the extractions - to diagnose fundamental features of the logic of contemporary urban capitalism as well as highlight continuities in the development model, therefore, compelling us to open a space to search for alternatives and potential trajectories of resistance. What seems novel about such an approach is what Gago and Mezzadra (2017) make explicit: the need to embrace economies of the periphery, and, therefore, to the very site of extractive activities. This analysis is not reduced to raw materials and fossils only but to a wider context of life - to break the disconnect between spaces and economies, emancipate from the merely passive position to the urban poor populations and make "dispossession become central; the category of exploitation itself is obscured, and the production of value by those populations, which finance itself already calculates as nonmarginal, is ignored. The concept of exploitation itself" (2017, p. 577). The authors, situating their critical analytical perspective from Latin America, suggest that "extraction cannot be reduced to operations linked to raw materials turned [to] commodities at the global level" but on the labor and life of populations, 
aiming at extracting value from them in such a way that it expands and complements the notion of exploitation "in terms of how the surplus is performed and appropriated" (p. 579). For them, the extractive relation presents itself rather differently from the relationship of exploitation formed in a factory based on the stipulation of a contract of wage labor. The utopian vision of a free-market society and its actual realization in space is striking given the potential coercive relationship between states and the hegemonic class on privatizing as many aspects of society as possible, including social services, culture, arts, politics and sciences, focusing on how cities have played a key role in this dynamic (Boano \& Vergara-Perucich, 2017). For Jaeggi, exploitation is "one of the evil that human beings" and is, therefore, a moral outrage and also an analytic-technical concept, "understood as [an] appropriation of the workers' surplus labor capitalism, that is, as [an] appropriation of that which the worker has produced in addition to what is necessary for the reproduction of his or her labor power. In other words, exploitation is the appropriation of surplus value. In its capitalist form, then, exploitation does not rest on open relations of domination or direct violence, but on the indirect coercion of circumstances" (Fraser and Jaeggi, 2018: 465). In this "promiscuous terrain," Mezzadra and Gago (2017, p. 482) suggest the need to disentangle "the 'polymorphism' of neoliberalism, advancing the way in which economies that are classically considered peripheral or marginal are incorporated into a dynamic of financial valorization, to the extent that a series of activities (from self-management to certain communitarian strategies), flows (of favors, migrations and exchanges), and spaces (such as the informal real estate market) are evaluated as profitable" (p. 583). Therefore, expanded extractivism is a formula that should be able to account for the action of multiple financial apparatuses in these territories that extract value from a social vitality.

Santiago's urbanisms experienced this struggle, and the form destroyed was replaced by different extractivisms from everyday life, which increased the profitability of urban capital but undermined the city as social space. To unpack the origins of the gigantomachy of Santiago, the following section aims to illustrate the way an in-progress welfare state ends up as one of the most radical forms of urban neoliberalism on the planet.

Addressing social progress with the Scientific urbanism: 1931 - 1958 
The Political Constitution of 1925 emerged amidst diverse social struggles happening in Santiago. The effects of the migration from rural to the city (Table 1) produced diverse issues related to urban sanitation, housing stock and services such as transport, health and educational facilities. These changes demanded new policies for adapting the urban space allowing the transformation for the sake of the whole society. The 1925 Constitution included an innovative regulation: it approved the expropriation of lands when a public project or the common interest required it. Specifically stating that: "The property right is subject to limitations or rules that demand in the maintenance and progress of social order, and, in this sense, the law could impose obligations or easements of public utility in favor of the general interests of the state, the health of the citizens and public health" (Ministerio del Interior, 1925: Art. 10.)

Figure 1. (about here)

Migration rates from rural to urban in Chile. Source: authors based on historical archive of National Census in Chile.

This was the only time in Chilean history when a constitutional act allowed expropriation in the name of social interest. The organisation of the city become a problem, and the ruling class understood that they needed a system to deal with it, following the traditional institutional attachment of the ruling class that historically has preferred to define their decisions and behaviour in rules, laws and official organisations (Gross, 1990). Therefore, politicians developed diverse instruments to advance in a top-down city making process which for years advanced through diverse explorations in order to find better ways to ensure the provision of urban solutions for the many. Most of this decision making was based on the foundations of Scientific Urbanism, an approach to urban development brought to Chile by the Austrian urbanist Karl Brunner. 
In 1931 Brunner created a programme named Urbanismo Científico (Scientific urbanism). The course presented the main theories of urban development and urban design from a positivist approach, embracing the intellectual influence of Booth, Geddes and Burgess mainly. Urbanismo Científico was founded over a strict correlation between the technical processes of urbanisation and the political administration of the decision making processes to make the spatial transformation legally viable in order to develop efficient cities (Pavez, 1992). Brunner's influence served the creation of the Planning Department of the Public Works Ministry, inaugurated in 1934 as a way to provide a comprehensive response to urban problems. Certainly, after Brunner's arrival, several public policies aimed to alleviate the issues related to the urbanisation of the population from the country. In 1931 (by order of Law 4931) the Popular Housing Bureau replaced the Superior Council of Social Welfare in order to organise the irregular settlements in cities. Nevertheless, the state was not capable of covering all the demand for housing. In 1938, Law 6172 allowed the Popular Housing Bank to build housing with public insurance funds. The approach was delivering institutional responses for socio-spatial needs.

Figure 2 (about here)

POU: Plano Oficial de Urbanización. Official Plan of Urbanisation for Santiago developed by Karl Brunner in 1934. Source: Archives of Facultad de Arquitectura y Urbanismo, Universidad de Chile

Scientific urbanism provided a pathway for organising the city based on statistics models as a key input to making decisions in relation to urbanism. Scientific urbanism was based on a central urban planning apparatus. For instance, between 1934 and 1939, Brunner defined the future of Santiago in his (Figure 2) Plano Oficial de Urbanizacion (Official Plan of Urbanisation). Its main innovation was the zoning of the central areas of Santiago in order to increase the stock of housing near the city centre. New neighbourhoods were imagined with eight-story buildings one plaza for every five blocks, following the model of Vienna. Brunner's plan defined areas for working-class towns near the areas were employment opportunities were concentrated . Likewise, housing typologies were proposed for some areas that were similar to the garden city in the immediate surrounding of the central districts. Brunner wanted to transform Santiago in the Vienna of South America: architecture 
composed of medium height buildings, boulevards and fine urban design to create something beautiful (Gross, 1991).

One of the main features of the scientific urbanism was the mixture of quantitative with projective methods. Most of the weight of the planning decisions were based on the study of land economic possibilities to project urban spaces, the need based on deficits, with special emphasis in defining where to invest based on the urgencies of the city as well as taking care of its aesthetical features. The objective of privileging statistical analysis was to ensure that public funds were correctly allocated considering the limited public resources at that time. As much as the scientific urbanism aimed to enhance the public experience of living in the city, the use of public budget for financing urban improvements increased the wealth of building companies' owners (Gross, 1991).

The Chilean urban experts defined a series of strategies for dealing with the demand for jobs in cities and its shortage on housing. For example, Law 7600 of 1943 determined that companies must invest $5 \%$ of their profits into building housing for their workers. Also, Law 9135 of 1948, created a series of benefits to facilitate access to homeownership for the middle class, fulfilling one of their demands (Gross, 1991). In 1952, President Gabriel Gonzalez created the Housing Corporation (CORVI), whose objective was building housing and public spaces, with a special preoccupation with low-income communities. In order to advance with a legal framework for the city, in 1953 the General Law of Construction and Urbanization was updated to make it suitable for the changes that had occurred in urban areas. In this update of the law, it was determined that there was a need for the urgent creation of municipal master plans for defining the function of urban areas (De Ramón, 2007). Through these regulations, the state attempted to deal with housing solutions and city planning in conditions of economic scarcity (Hidalgo Dattwyler, 2004; Rivera, 2012). These new institutional regulations were the result of the implementation of scientific urbanism in Chile, although it never crossed the frontiers of the interests of the hegemonic class. Moreover, the demand for housing grew faster than the capacity of the state to provide solutions. Society gathered in community organisations to build an agenda capable of empowering their voices and generating changes that would transform the face of the city. 
One of the better examples of this emerging social empowerment refers to the practice of people producing their vivienda autoconstruida (self-constructed housing) based on what is known as tomas (squats). In 1957 the occupation of lands in La Victoria began, near Santiago's downtown. Thousands of families constructed their houses in a self-managed approach. Various political institutions like the Communist party, the Socialist party, students and workers unions and the Catholic Church assisted people with organising these tomas ${ }^{\mathrm{ii}}$. These occupations contested a sacred right for the ruling class: private property. La Victoria soon became the model and the inspirational experience for many other communities (Espinoza, 1988). People went beyond the law, fighting for their right to shelter, producing a clash between their needs and the interests of capital (Cortés, 2014). This happened in the very centre of Santiago. In the eyes of the ruling class it meant a threat to the revered private property right.

Besides these issues related to contested territories, the economy was accumulating inflation that increased for decades without stopping (Salazar, 2003). Looking for better solutions, in 1958 people elected a businessman - Jorge Alessandri - as president, to see if his brilliant entrepreneurial career would enhance the economic performance of the country at that time. While economic growth improved under his government, tomas continued emerging despite Alessandri doubled the investment and the production of social housing. The plan was to incorporate the private sector more actively in the production of social housing. The goal was building 538,700 new dwellings between 1961 and 1970, considering that $75.5 \%$ of these new units would be for low-income communities (Arriagada, 2004). This plan started in 1960, when Alessandri implemented a decree which included taxing benefits for middleclass housing (DFL2), promoting a garden city model of urban development, mostly located in the borders of the city. However, this policy was regressive. The high-income families took advantage of this decree and built their houses far from the city centre using a regulation that was supposed to help middle-income families. In the interpretation of Patricio Gross, the regulation of DFL2 missed a point because it "didn't restrict some areas of the city, which allowed that high-income person to exploit these benefits, settling on the east side of the city, increasing the process of spatial segregation" (Gross, 1991: 39). Consequently, the city 
concentrated the localisation of urban population in certain areas depending on their purchasing capacity: the richest people built their houses in Las Condes and Vitacura (eastNorth), the middle classes in Providencia, Nuñoa (Centre-east) and the east side of Santiago, while low-income families occupied the rest of the city and the fringes. The distribution of the richest families, middle-income families and the lower class outlined a segregated space. This issue was accompanied by the expansion of squatting practices and the subsequent contestations around them.

From the scientific urbanism to the city of the masses: 1958 - 1973.

Alessandri's government implemented a modest agrarian reform to redistribute land in rural areas and to give peasants landownership rights. This was an initiative fuelled by the Catholic Church in Latin America. Nevertheless, the timidapproach of Alessandri's administration meant that the agrarian reform did not alleviate the processes of contestation on private property. In 1964, people elected Eduardo Frei, who proposed a revolución en Libertad (revolution with freedom) supported bythe Democratic Christian Party. This revolution with freedom was a mix of socialist strategies and free-market economics, aspiring to develop a Chilean version of the Keynesian model of the state.

Hence, in 1964 - when Frei assumed the administration - the state took on a redistributive role and subjugated private property rights to society's common good. Land acquired a social role. In spite of the economic crisis because of persistent inflation that was pressuring household budgets of working-class families, the political discourse promised a socially just future based on redistributive policies. The administration of Eduardo Frei (1964-1970) and Salvador Allende (1970-1973) advanced in this path to a more just society based on deepening democratic instruments. In Frei's administration, the Catholic ideology of social doctrine was applied, aiming to create a more just society, using the state as an effective agent for distributing opportunities and benefits for people. Their strategy considered nationalising natural resources, fostering economic productivity, modernising the administrative apparatus and developing a state capable of providing wellbeing through social services, thus covering the basic demands of human life. The agrarian reform of Frei aimed to increase the productivity of lands that in many cases were under-exploited by landlords. If peasants were 
involved in labouring the soil and also in the earnings, the productivity of those underexploited plots would soar. Also, this was a straightforward form of distributing the benefits of agrarian and livestock activities among low-income communities. Indeed, the agrarian reform constituted an approach to spatial justice that also had a version in urban development. Frei launched a series of programmes of social housing in which participatory processes were included.

These strategies alleviate the possible urban collapse of Santiago, given the incessant migration to the central city of the country which increased 37\% between 1960 and 1970 ( INE, 2018). Beyond this agrarian reform, the government of Frei was not particularly a threat to private property, although he connected this right to have solidarity with the poor to ensure social progress. Nevertheless, while low-income communities were occupying private plots of land, the ruling class started to engage politically in defending their ownership rights.

From the colony, the urban poor in Santiago applied self-construction as a strategy for settling near the urban core of the city. In general, this was a more organic process of land occupation in which people met when occupying the space and not before. However, as urbanization advanced and Santiago became more populous, the urban poor started to organize better to take the land and scale up the self-construction process from individual housing to entire neighborhoods. This implied a change in the approach to housing for the urban poor, from individual responses to a more collective action of popular urbanization, even when these strategies implied the contestation of land rights. From the pursuit of citizenship rights to a political struggle, Santiago's urban poor population became a significant political actor in the sixties and beyond.

Between 1957 and 1973, urban land became a key element in the political dispute. In this period Chileans had started to demand more direct participation in decision-making processes regarding their participation in the production of their cities and being included in the benefits of living in Santiago. The creation of new institutional regulations to foster participation and empowering communities aimed to address the demands for spatial justice emerging from tomas. In 1965 the National Office of Planning (ODEPLAN) and the Housing 
and Urbanism Ministry (MINVU) were created for dealing with these issues in particular. As part of the Housing and Urbanism Ministry, the Central Bank of Savings and Loans (SINAP), The Housing Corporation (CORVI), The Corporation of Urban Enhancement (CORMU), The Corporation of Housing Services (CORHABIT) and the Corporation of Urban Works (COU) were created.

Such renewed institutional frameworks aimed to construct a more transparent and just urban life reducing tensions produced by land struggles. To connect the social struggle in cities with government plans, the role of urban practitioners was fundamental. Many scientific urbanists embraced a social vision and they influenced the way of approaching urban processes and engage directly with communities in elaborating plans and ideas to design urban spaces. In this period a group of urban experts working with at the grassroots level such as Miguel Lawner, Fernando Castillo Velasco, Ida Vera, Miguel Eyquem, and Leopoldo Benítez ${ }^{\mathrm{iii}}$, emerged as new socially inspired professionals.

Figure 3 (about here)

Areas of Santiago where social housing programmes were built between 1970 and 1973.

Source: authors.

During the Frei and Allende period, the construction of housing was one of the most visible public policies, as well as the provision of transport, sanitation, public spaces, cultural facilities, and housing for the dispossessed. An interesting strategy was building social housing in central areas of the cities, especially Santiago, aiming to reduce residential segregation and increase access to amenities and central areas for low-income communities (Figure 4). The ideas of the political class about urban development attempted to ensure social integration in cities. In this approach to planning the city, CORMU and CORVI participated in the provision of urban projects for the poor and middle class by defining the technical design of housing, defining its location, and calling bids for its construction by private companies. Some of the emblematic housing projects built under this scheme were Unidad Vecinal Portales (1966) as part of the Particular Employees Programme, Remodelación República (1967) as part of a CORVI program for low and middle-income 
families, and Tupac Amaru (1971) as a CORMU project for low-income families. Also, selfconstruction became an alternative promoted by the government. For example, in 1965 Frei organised a participatory process for designing houses for low-income and middle-class families in Santiago. The name of this initiative was Operación Sitio, supported by the mayor of La Reina comuna, the architect Fernando Castillo Velasco (Quintana, 2014). It consisted of families drawing their 1:1 scale blueprints of dwelling units on the ground, and then the state constructing the houses based on the people's design. Architects assisted people in designing the houses. However, these operations contributed in consolidating new neighbourhoods in urban peripheries, notso close to the access to transport and amenities..

Figure 4 (about here)

The localisation of tomas in Santiago in 1972. Source: authors based on Castells 1987

Despite the institutional transformations, the squats multiplied (Figure 4); in 1969 in Santiago alone 35 new tomas appeared (Gross, 1991): state innovations were not enough to cope with the accelerated urbanisation processes. Empowered people, the democratisation of private property, and a frightened ruling class were not a good mix (Gómez-Leyton, 2000). Political radicalisation, international interest in the raw materials available in the national territory, and rising inflation that had been plaguing the country since the forties fostered an already complicated social tension (Salazar, 2003). Space was under dispute and politicians engaged in organising the demand of dispossessed people to ensure the defence of private property on the one side and guiding the struggle for spatial justice on the other side. In this very moment, the political project of Salvador Allende and the Unidad Popular proposed a pathway for redistributing power and ensuring social justice. It was a revolution with $\operatorname{chich} a^{\mathrm{iv}}$ and empanadas, the so-called Chilean way to socialism (Ayres, 1973). Detached from the methodologies used by the Cuban revolution, Allende bet that he could build a socialist state within the institutional frameworks of the Chilean democratic republic, without using violence (Nolff, 1993). In this goal, space was a key issue, a city based on the principles of the Chilean way to socialism (Cofré Schmeisser, 2012). The production of space and territorial productivity would be at the centre of the political transformations developed by Allende for building a fairer society (Lawner et al., 2008). On the opposite side, the ruling class, the land owners, started to organise their influences and political power to defend their 
position (González, 2001) and property rights (Gómez-Leyton, 2000). For them, Allende represented a threat (Fontaine, 1993). In this dispute over defending property rights, the position of the military forces was fundamental. The contestation for land was not between equals. Allende received support from some prominent members of the military forces ${ }^{\mathrm{v}}$, which lent security to the implementation of his programme. Nevertheless, within the army, the division was not so even, and oligarchical influence was higher in some emergent but powerful figures of the army, navy and air forces. Historically, evidence suggests that the military forces have been loyal to the oligarchy for defending property rights as the most sacred value of the nation (Salazar, 2003). The historian Gabriel Salazar counts 23 times in which Chilean military forces have fired their guns against non-ruling class Chileans, smashing every attempt to produce a fairer society (Salazar, 2012). This evidences that force - not justice - has been the engine of Chilean history ${ }^{\text {vi }}$. Allende was elected president by the majority and confirmed by the parliament, but not by the ruling class or landowners who saw in Allende's political project a chance to losing their social exclusiveness.

In three years, Allende's administration achieved a comprehensive implementation of urban policies through the coordination of ODEPLAN (Oficina de Planificación Nacional) and the Urban Development Department. The state took part in urban development as one more member of the market, influencing prices and trends though not controlling it (González, 2001). The government acted as a stakeholder, fostering a different approach to the city, starting with the empowerment of the grassroots in a well-intentioned bottom-up method of urban design (Cofré Schmeisser, 2012). In Allende's programme, the objectives for urban development were: increasing access to good housing, reducing residential segregation and using the land as an asset to redistribute the benefits of urban life. Community engagement was fundamental for fostering the revolutionary spirit of Allende's programme.

The plan was to build houses around employment areas, namely Santiago's downtown. Several housing projects were designed and developed in Santiago: Che Guevara (1970), Villa San Luis (1970), Cuatro Alamos (1971), Mapocho-Bulnes (1971), Plaza Chacabuco (1971) and Pozos Areneros (1971), to mention just few neighbourhoods. These project typologies followed the international style, with four-story buildings inserted in public spaces 
and with common facilities. These strategies, applied in Santiago and other cities, resulted in a significant decrease in the housing deficit, from 592,324 in 1970 to 419,000 in 1974.Allende's ambitious housing program did reduce the housing shortage, but during his government, the number of informal settlements in Santiago reached 275, and 16.3\% of Greater Santiago inhabitants lived in a campamento (Santa María, 1973). As Frei and Allende opted to avoid the repression of new informal settlements, the occupiers saw in the land occupation a protest against their limited access to land use for economic reasons and also a demand for citizenship rights from the state (Hidalgo-Dattwyler, 2019). Both Frei and Allende tackled these demands with public policies and specific housing programs by engaging in dialogue with people but, at the same time, neglected the interests of the elite and their historical aspirations of separating themselves from the rest (Gross, 1991). Thus, land occupations not only served to find people a space to live and organize a political struggle but also to fuel tension in the elite who saw how their neighborhoods were populated by what was labeled as poblaciones callampa (mushroom neighborhoods).

Most of the high-income landowners preferred to have the poor living far away from their neighbourhoods. One of the emblematic cases was the Villa San Luis (Figure 5) in the heart of Las Condes district. This new social real estate provoked an awkward reaction from the elite members who were concerned about losing the exclusivity of their neighbourhood (Gross, 1991). The urban poor, following centres of opportunity, were already building informal settlements in Las Condes so Allende tried to formalise the spaces for providing more dignity to urban poor in those areas. As a singular case, Villa San Luis was a strategy for changing the status of this settlement from informal to a legal housing estate. Also, it was an example of allowing low-income housing communities in high-income districts. In the view of the landowners, the exclusivity of some areas of Santiago was contested not only by the urban poor but also by the government.

Figure 5 (about here)

Villa San Luis Building in 2015. The estates were sold to real-estate companies that made a new financial district (Nueva Las Condes). Source: authors. 
Both Frei and Allende's political agendas were facing demographic change and society more aware of its rights specifically demanding better living conditions. During the governments of Frei and Allende, the ruling class was frustrated. For the first time in Chilean history, their capacity for influencing the government was reduced. They were scared of the day when these masses would batter down their doors and take all their possessions. They saw the danger of the genuine democracy that was being forged which threatened their social status. The solution to their social discomfort was fierce and merciless. Like many other times in history, the Chilean army aimed their guns at other Chileans to defend the private property of the few at the cost of the many. On September 11th, 1973, the democracy ended with the coup-d'état led by Augusto Pinochet. Private property was safe again. A neoliberal revolution started.

\section{The big bang of global neoliberalism and the death of Chilean urbanismo}

The materialisation of neoliberalism occurred in Santiago as the operationalisation of a theory of political economy developed by Milton Friedman who gently shared his ideas in 1975 with the Chilean dictator, Augusto Pinochet (Daher, 1991; Solimano, 2014). On $11^{\text {th }}$ of September 1973, a coup-d'état overthrew the democratic government of Salvador Allende. Recognising the need for economic competency, Pinochet sought counsel from notable scholars opposed to Allende's ideas (Solimano, 2014). In 1975, he assigned key ministries to a group of economists known as the Chicago Boys ${ }^{\text {vii }}$, who implemented a programme of political economics ${ }^{\text {viii }}$ that came to be known as neoliberalism (Harvey, 2005). The proposal aimed to reduce the size of the state and to increase reliance on free-market economics as the principal instrument for the development of the country, defending private property and fostering entrepreneurialism as the better way to conduct the progress of the country (Arancibia Clavel and Balart, 2007). Pinochet accepted these ideas. The model promised that the free market economics would lead society to individual freedom, an idea that was presented to Pinochet by Milton Friedman himself. He went to Chile and met with Pinochet. The 21st of April of the same year, Milton Friedman wrote to to Pinochet about the transformations to address in Chile: "I believe gradualism is not feasible" (Friedman and Pinochet, 1975). Friedman was explicit in saying that this was a "shock programme" 
(Friedman and Pinochet, 1975: 592) that aimed to resolve the issues of inflation in months. Pinochet took the shocking idea seriously and repressed every opposition to the programme. “The plan is fully applied" (Friedman and Pinochet, 1975: 594) replied Pinochet.

Chile in the 1960s was recognized for a great health and educational systems on the region, with a lively industrial sector and a rapidly growing middle class (Klein, 2010). There was a sharp switch in the dictatorship's policies towards what we could call the first neoliberal state in the world. Since then, the state has encouraged private initiatives for social security and has advanced the privatisation of as many state functions as possible. A new era started, as private property and profit-driven decisions reshaped society as a whole (Atria et al., 2013). "Neoliberalism abandons the liberal conceit of a separation between political and economic realms of life." (Davis, 2017: 4). In theory, the economic growth generated by consumption and productive activities would trickle down, reaching everyone and improving the lives of the people. An ideal scenario for the frustrated ruling class after taking back their hegemonic position in politics.

Therefore, the neoliberal transformation of Chile required a new urban development model. The first measure was a tax reform to foster the investment in housing construction. In 1975, Pinochet signed the decree 910 which reduced the tax for building activities to increase the role of this industry in the economic recovery of the country. Both the construction and selling of housing units were VAT exempt, which fostered the investment in building industries from private sectors, reducing the participation of the government in these economic activities. Years later, for continuing with the neoliberalisation of urban development, the Housing Ministry and the Public Works Ministry were redefined, and the urban planning apparatuses of the state were dismantled (Valencia, 2008). Michael Janoschka and Rodrigo Hidalgo (2014) explain that neoliberal urban policies transformed the relationship between social, political and economic actors, from relationships between citizens to relationships between consumers. Santiago, as a neoliberalised city, started to become a platform populated by urban components for speculation, with a civil society incapable of contesting a mercantilist notion of space (Rodriguez and Rodriguez, 2009). These changes came from a particular urban theory. 
Arnold Harberger was a professor from the University of Chicago, who published an article explaining the importance of deregulating land for reducing housing prices by sprawling the urban area of Santiago (Harberger, 1979). His ideas provided the theoretical basis for the creation of the National Policy of Urban Development on $30^{\text {th }}$ November 1979 by the Presidential Decree 420 (Daher, 1991). The policy presented three principles:

- The land is a non-scarce resource; therefore, its use and value are defined by its profitability. It is subject to free trade, and restrictions on urban sprawl will be removed to allow the natural expansion of urban areas, following market trends.

- Housing scarcity will be relieved by private building companies, promoted by the state, but it is the responsibility of the market to deal with dwelling demand.

- Every improvement in the environment and cities financed by the state should be oriented towards making land more profitable. (CNDU, 2015).

The big bang of neoliberalism occurred in 1975, but the expansion of the neoliberal universe was ongoing in the form of policies, institutional transformations, violence, social alienation, speculation, and increasing inequality. Thanks to the masterminds of the Chicago Boys and the agreement of Pinochet, private property would return to be an untouchable right in Chile. The social function of land, the expropriation for the common good and the state as a stakeholder in urban development were banished from the country. Any sign of social justice was evicted, and the law of the survival of the fittest (or the richest) became the main criterion for social order. The owners of the land reassured their hegemonic power, ensuring that they would control the economy, the government, the democracy, the meaning of freedom and of course - urban society as a whole. 


\section{Extraction or resistance}

Excavating the historical moments of the urban governance under Frei, Allende and the beginnings of Pinochet's dictatorship, even if cursory, allows a reflection on the role of the ruling elite in shaping the city as one of the main components that justify the emergence of neoliberal urban development: profit-oriented and in defence of the private property. The main engine of Santiago's urban transformations has been individual property rights. Santiago's urban space resulted from a historical dominance of the land by a ruling class whose main goals has been extracting value from space by construction and commerce of urban products. This explain why defending private property rights has become one of the main objectives of the ruling class.

Extractivism is a new form of the complete explosion of value from every aspect of the urban life. Extractivism has become the totalitarian life form of the world and of a new citizen dimension. Exploitation, from extraction, to forms of real and formal subjugation to to imprinting are pervasive of the urban condition and give rise to vital subsumption. The techniques of vital subsumption include everything from birth to death, the entry and exit of the territory, the crossing of the borders, preventive quarantine, protective custodies, eugenics, citizenships and so on. This bundle of processes, multilateral and complex, signal the true spaces of capital: extracting values directly from human qualities as living beings. In Chile, and particularly in Santiago, the political and economic power was and is still in the hands of the property-owners. This condition has remained the same for decades, and it explains the relevance given to defending this right either by law or by using military force. Therefore, democratic institutions will be limited by their will. For instance, the only time in history that distribution of land for social well-being occurred was during the governments of Frei and especially with Allende, but the result was a coup-d'état and 17 years of a repressive dictatorship that developed a political constitution that ensured property rights prevailed.

As a final reflection, the role that urban experts may play in the democratisation of Santiago is key, as well as the possibility of democratising the society by developing more democratic 
urbanisms, but doing so requires a fierce contestation of neoliberalism. Alex Golub (2014), gives an ethnographic account of the relationship between the Ipili, an indigenous group in Papua New Guinea, and a large international gold mine operating on their land. He describes a context where a corporate actor has the ability to translate all the negotiations, intrigues, calculations, acts of persuasion and violence, thanks to which an actor or force takes, or causes to be conferred on itself authority to speak or act on behalf of another actor or force. In discussing both the strategies of imperial bureaucracy and colonial cosmogony of Leviathan extractivism, Golub suggests that it is important to recognize that it is not simply globalization and resource frontiers that lead to questions regarding the nagging intangibility yet monstrous efficacy of extraction, but the tenacious struggles and pervasive action across time and space of the Ipili that made possible some sort of negotiation in resisting the multinational company. The city shows its plastic soul, the place that concentrates, absorbs, transforms, generates and destroys. And indeed, for us, only the fertile encounter between philosophy, critical theory and urbanism, and the ontological implication of re-thinking the city, can be instrumentalised to develop urgent interpretative tools that support and sustain struggles, resistances in the present Gigantomachy.

\section{References}

Arancibia Clavel P and Balart F (2007) Sergio de Castro, El Arquitecto Del Modelo Económico Chileno. Santiago: Biblioteca Americana.

Arriagada C (2004) Chile, Un Siglo de Politicas de Vivienda y Barrio. Santiago: Ministerio de Vivienda y Urbanismo - DITEC.

Atria F, Larrain G, Benavente JM, et al. (2013) El Otro Modelo. Santiago: Random House Mondadori.

Ayres RL (1973) Electoral constraints and the chilean way to socialism. Studies in Comparative International Development 8(2): 128-161. DOI: https://doi.org/10.1007/BF02809998.

Boano C (2017) Ethics of a Potential Urbanism: Critical Encounters Sign and the Built Environment. London: Routledge.

Boano C and Vergara-Perucich F (2017) Neoliberalism and Urban Development in Latin America. Oxon - New York: Routledge.

Boas TC and Gans-Morse J (2009) Neoliberalism: From new liberal philosophy to anti-liberal slogan. Studies in Comparative International Development 44(2): 137-161. DOI: 10.1007/s12116-0099040-5. 
Brenner N, Peck J and Theodore N (2012) Alternatives of Neoliberalism. London: Bedford Press.

Brown W (2016) Sacrificial Citizenship: Neoliberalism, Human Capital, and Austerity Politics. Constellations 23(1): 3-14. DOI: 10.1111/1467-8675.12166.

Cattaneo Pineda RA (2011) Los fondos de inversión inmobiliaria y la producción privada de vivienda en Santiago de Chile: ¿Un nuevo paso hacia la financiarización de la ciudad? EURE (Santiago) 37(112): 5-22. DOI: 10.4067/S0250-71612011000300001.

Celik Z and Favro D (1988) Methods of Urban History. Journal of Architectural Education 41(3): 49.

CNDU (2015) Política Nacional de Desarrollo Urbano. Santiago. DOI: http://cndu.gob.cl/wpcontent/uploads/2014/10/L4-Politica-Nacional-Urbana.pdf.

Cofré Schmeisser B (2012) La ciudad socialista: visión y práctica urbana del Partido Comunista de Chile, 1967-1973. Revista Izquierdas (13). Universidad de Santiago de Chile.

Cortés A (2014) El movimiento de pobladores chilenos y la población La Victoria: ejemplaridad, movimientos sociales y el derecho a la ciudad. EURE (Santiago) 40(119): 239-260. DOI: $10.4067 / \mathrm{S} 0250-71612014000100011$.

Daher A (1990) Neoliberalismo urbano en Chile. Estudios Públicos: 281-299.

Daher A (1991) Neoliberalismo urbano en Chile. Estudios Públicos: 281-299.

Davis LE (2017) Financialization and Investment: a Survey of the Empirical Literature. Journal of Economic Surveys 31(5): 1332-1358. DOI: 10.1111/joes.12242.

De Ramón A (2007) Santiago de Chile. Historia. Catalonia.

Espinoza V (1988) Para Una Historia de Los Pobres En La Ciudad. Santiago: Ediciones SUR.

Fernandez R and Aalbers MB (2016) Financialization and Housing: Between Globalization and Varieties of Capitalism. Competition and Change 20(2): 1-20. DOI: $10.1177 / 1024529415623916$.

Follain JR and Giertz SH (2012) Preventing House Price Bubbles: Lessons from the 2006 - 2012 Bust.

Fontaine J (1993) Transición Económica y Política en Chile: 1970-1990*. Centro de Estudios Públicos 50(otoño 1993): 229-279. Available at: https://www.cepchile.cl/cep/site/artic/20160303/asocfile/20160303183755/rev50_jafontaine.p df.

Fraser N and Jaeggi R (2018) Capitalism: A Conversation in Critical Theory. London - New York: John Wiley \& Sons.

Friedman M and Pinochet A (1975) Friedman-Pinochet Correspondence.pdf. Available at: http://wwww.naomiklein.org/files/resources/pdfs/friedman-pinochet-letters.pdf. 
Gago V and Mezzadra S (2017) A Critique of the Extractive Operations of Capital: Toward an Expanded Concept of Extractivism. Rethinking Marxism 29(4): 574-591. DOI: 10.1080/08935696.2017.1417087.

Golub A (2014) Leviathans at the Gold Mine. Leviathans at the Gold Mine. Duke University Press. DOI: $10.1215 / 9780822377399$.

Gómez-Leyton JC (2000) Democracia y Propiedad Privada En Chile 1925-1973. FLACSO.

González M (2001) Chile, La Conjura: Los Mil y Un Días Del Golpe. Ediciones B.

Greene M, Rosas J and Valenzuela L (2011) Santiago Proyecto Urbano. Santiago: Ediciones ARQ. Gross P (1990) Santiago de Chile: ideología y modelos urbanos. EURE. Revista Latinoamericana de Estudios Urbano Regionales 16(48). Universidad Católica de Chile, Centro de Desarrollo Urbano y Regional.: 67.

Gross P (1991) Planificacion Urbana Y Modelos Politicos *. XVII: 27-52.

Harberger A (1979) Notas sobre los problemas de vivienda y planificación de la ciudad. Revista AUCA 37(1): 39-41.

Harvey D (2005) A Brief History of Neoliberalism. New York: Oxford University Press.

Hidalgo-Dattwyler R (2019) La Vivienda Social En Chile y La Construcción Del Espacio Urbano En El Santiago Del Siglo XX. 2nd ed. Santiago: Ril Editores.

Hidalgo Dattwyler R (2004) La vivienda social en Santiago de Chile en la segunda mitad del siglo XX: Actores relevantes y tendencias espaciales. Instituto de Geografía, Pontificia Universidad Católica de Chile: 219-241.

Hobsbawm E (1971) From Social History to the History of Society Author. Daedalus 100(1): 20-45. Available at: https://www.jstor.org/stable/20023989.

Instituto Nacional de Estadísticas (INE) (2018) Censos históricos INE. Available at: http://www.ine.cl/estadisticas/censos/censos-de-poblacion-y-vivienda (accessed 2 May 2016).

Janoschka M and Hidalgo R (2014) La Ciudad Neoliberal: Estímulos de Reflexión Crítica. Santiago: Editorial Universitaria.

Klein N (2010) Milton Friedman did not save Chile. The Guardian, 3 March. London. Available at: https://www.theguardian.com/commentisfree/cifamerica/2010/mar/03/chile-earthquake.

Klein N (2011) The Shock Doctrine. EuroEconomica: 565. DOI: 10.1068/d2604ks.

Lawner M, Soto H and Schatan J (2008) Salvador Allende: Presencia En La Ausencia. Lom Ediciones.

Lefebvre H (2003) The Urban Revolution. Minneapolis: Univeristy of Minnesota Press.

Ministerio del Interior (1925) Constitución Política de la República de Chile, 1925. Santiago: Congreso Nacional. 
Nolff M (1993) Salvador Allende: El Político, El Estadista. Ediciones Documentas.

Pavez MI (1992) Precursores de la enseñanza del urbanismo en Chile periodo 1928-1953. Revista de Arquitectura 3(3). Santiago: 2-11. DOI: 10.5354/0719-5427.2014.31061.

Quintana F (2014) Urbanizando con tiza. ARQ (Santiago) (86): 30-43. DOI: 10.4067/S071769962014000100005.

Rivera Á (2012) Historia de la Política Habitacional en el Área Metropolitana de Santiago. Revsita CIS 16(16): 27-44.

Rodriguez A and Rodriguez P (2009) Santiago, Una Ciudad Neoliberal. Quito: OLACCHI.

Rolnik R (2013) Late Neoliberalism: The Financialization of Homeownership and Housing Rights. International Journal of Urban and Regional Research 37(3): 1058-1066. DOI: 10.1111/14682427.12062 .

Rosas G (2007) The Fragile Ends of War. Social Text 25(2): 81-102. DOI: 10.1215/01642472-2006028.

Rossi U and Vanolo A (2015) Urban Neoliberalism. In: Wright J (ed.) International Encyclopedia of the Social \& Behavioral Sciences. London: Elsevier, pp. 846-853. DOI: 10.1016/B978-0-08097086-8.74020-7.

Salazar G (2003) Historia de La Acumulación Capitalista En Chile (Apuntes de Clases). Santiago: LOM Ediciones.

Salazar G (2012) Clase Magistral - Gabriel Salazar: Padres y Madres de la Patria - YouTube. Available at: https://www.youtube.com/watch?v=8J2IHjm8muM (accessed 16 November 2017).

Salazar G and Pinto J (2014) Historia Contemporánea de Chile III. La Economía: Mercados, Empresarios y Trabajadores. Santiago: LOM Ediciones.

Salcedo R and Rasse A (2012) The Heterogeneous Nature of Urban Poor Families. City \& Community 11(1): 94-118. DOI: 10.1111/j.1540-6040.2011.01385.x.

Santa María I (1973) El desarrollo urbano mediante los 'asentamientos espontáneos': el caso de los 'campamentos'chilenos. EURE: Revista Latinoamericana de Estudios urbanos y Territoriales 3(7): 103-112. Available at: http://mail.eure.cl/index.php/eure/article/download/842/699.

Scarpaci JL, Infante RP and Caete A (1988) PLANNING RESIDENTIAL SEGREGATION: THE CASE OF SANTIAGO, CHILE. Urban Geography 9(1): 19-36. DOI: 10.2747/02723638.9.1.19.

Solimano A (2014) Neoliberalismo y Desarrollo Desigual : la Experiencia Chilena. (2013): 1-19.

Spencer D (2016) The Architecture of Neoliberalism. London: Bloomsbury.

Springer S (2016) The Handbook of Neoliberalism. Handbook of Neoliberalism. 
Stiglitz JE (2010) Freefall: America, free markets, and the sinking of the world economy. WW Norton \& Company: 258. DOI: 10.1111/j.1468-2346.2008.00711.x.

Valencia M (2007) Revolución neoliberal y crisis del Estado Planificador. El desmontaje de la planeación urbana en Chile. 1975-1985. Diseño Urbano y Paisaje 4(12): 1-25.

Valencia MA (2008) El desmontaje de la planeación urbana en Chile 1975-1985. La nueva política de desarrollo urbano y transformaciones en la cultura metropolitana (segunda parte). Diseño Urbano y Paisaje 5(15): 1-23.

ii Tomas is the Chilean name given to squatters.

${ }^{\text {iv }}$ Chicha is the Chilean national drink, a sort of cheap wine.

${ }^{v}$ René Schnider was the chief commander of the Chilean Military Forces and its commitment to defend Allende's Project was several times confirmed by himself by saying that he would protect the constitutional presidency of Chile with his life. Schnider would die from a gunshot in 1970. A fascist fanatic killed him in the entrance of his house.

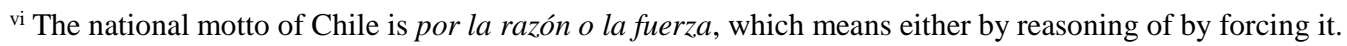

${ }^{\text {vii }}$ Some of them were Pablo Barahona (President of Chilean Central Bank 1975-76 and Economics Minister 1976-78), Álvaro Bardón (President of Chilean Central Bank 1977-81; Sub-secretary of Economics 1982-83), Hernán Büchi (Economics Minister, 1979-80 and Finance Minister 1985-89), Jorge Cauas (Finance Minister 1974-77), Sergio de Castro (Economics Minister 1975-76; Finance Minister 1976-82), Miguel Kast (Planning Minister 1978-80; Labour and Social Security Minister 1981-82; President of Chilean Central Bank 1982), Felipe Lamarca (Director of Internal Revenue Service 1978-84), Rolf Lüders (Economics Minister 1982; Finance Minister 1982-83), Juan Carlos Méndez González (Budget Director 1975-81), Juan Ariztía Matte (Superintendent of Private System of Pensions 1980 - 1989). These were the main advisors of Pinochet during the implementation of neoliberal policies, together with the lawyer Jaime Guzman. 